\title{
Fifty years after the death of July Stephanov (1932-1966)
}

If he were alive today, he would be 84 . This would be a solid age, at which most people have left many things behind. However, on his birthday fifty years ago, July Stephanov ended up at a location that turned out fatal not only for him but also for many others. At noon on May 1, 1966, prolonged rainfall in NW Bulgaria resulted in catastrophic flooding that submerged hundreds of houses and killed more than 100 people in the town of Vratsa. Sadly, July Stephanov and his relatives were also among the victims, whose bodies had been stacked for identification on the field of the town stadium after the disaster. No one knows the whole truth about this tragedy. Perhaps, it was a mix of human negligence and heavy weather, but it does not matter. It is time that is always the most objective judge and that has already said its words. The trivial gradually passed into oblivion, but the scientific life of July Stephanov left a very bright trail, and he will be remembered even by those who know him only by his papers.

Although he was only 34 years old when he died, in the only seven years' span of his scientific career, July Stephanov made valuable contributions, which have placed him at the forefront of the Bulgarian palaeontology and stratigraphy. His brilliantly original taxonomic studies of the Bathonian ammonites from northwestern Bulgaria raised him, when he was still alive, at the level of the world's leading authorities. Even now, it is not possible to do a study on the ammonite genera Oecotraustes and Siemiradzkia without using his comprehensive revisions of these ammonites. He was amongst the pioneers who realized the necessity of using parallel schemes of different stratigraphic units in Bulgaria, guided by a National Stratigraphic Code. His biggest contribution was the appearance of the Bulgarian translation of the International Code of Zoological Nomenclature, of which he was managing editor. There is no doubt that the publication of the rules of the zoological nomenclature in our own language was decisive for increasing the level of Bulgarian science.

I am not going to make an extensive reference to the achievements of July Stephanov. A few accounts have been published and have adequately covered these matters (Sapunov, 1967, 1982; Tchoumatchenco and Nikolov, 2016). We are indebted to these narratives for reminding us who he was and what he did. Interest-

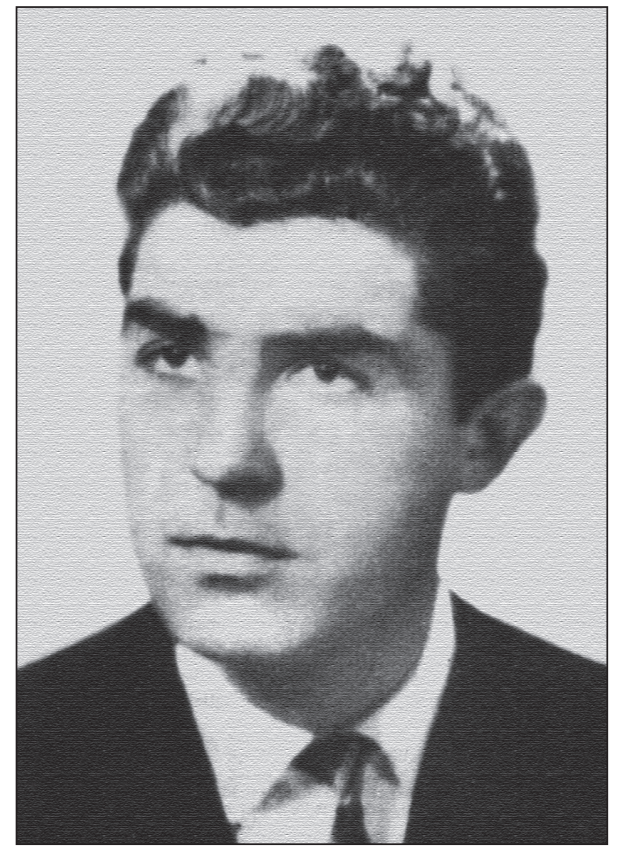

ingly, July Stephanov once shared with friends that he felt that he had only a short time to live. He confided in them, however, that he had no fear of death but would regret leaving life as there was so much he wanted to explore. Although he departed this life too early, and even though 50 years have passed since then, he is still alive through his works.

Lubomir Metodiev

\section{REFERENCES}

Sapunov, I. 1967. Juli Stephanov (1 May 1932 - 1 May 1966). Bulletin of the Geological Institute, Series Paleontology, 16, 7-16 (Bulgarian and English version, with list of contributions).

Sapunov, I. 1982. Juli Stephanov (1. V. 1932 - 1. V. 1982). Review of the Bulgarian Geological Society 43 (3), 314-315 (in Bulgarian).

Tchoumatchenco, P., Nikolov, T. 2016. Compendium of Bulgarian palaeontologists (1896-31.12.2015). Part II. L-Ya. Review of the Bulgarian Geological Society 77 (2-3), 31 (in Bulgarian). 